\title{
The History of Studying Climate Change in the Krasnoyarsk Territory
}

\author{
Natalia P. Koptseva and Natalia N. Seredkina* \\ Siberian Federal University \\ 79 Svobodny, Krasnoyarsk, 660041, Russia
}

Received 14.07.2017, received in revised form 08.08.2017, accepted 21.08.2017

\begin{abstract}
The article is devoted to the analysis of the climate change studies' history in the Krasnoyarsk Territory (Krai). The authors identified four stages; each has some characteristic historical events, the results of scientific research, which influenced the development of regional climatology and increased knowledge about the Krasnoyarsk Territory's climate. The dynamics of the scientific knowledge development concerning climate was possible to study on the basis of the content analysis of both the works of the first Siberian climate researchers (A.I. Voeikov, A.F. Middendorf, A.P. Stepanov, etc.), and modern scientific works (D.F. Zhirnova, V.S. Myglan, B.T. Kochkin, etc.). The study's result was an orderly knowledge system about the history of studying climate change in the Krasnoyarsk Territory. A tendency has been found to study the regional climate not only from the point of its change towards an increase in the average air temperature, but also from the point of the influence of anthropogenic factors on the increase in climatic indicators and climate change - on the life quality for the population of the Krasnoyarsk Territory.
\end{abstract}

Keywords: global warming, climate change, history, Krasnoyarsk Territory, meteorological observations.

The reported study was funded by Russian Foundation for Basic Research, Government of Krasnoyarsk Territory, Krasnoyarsk Regional Science and Technology Support Fund (project № 17-16-24601).

DOI: 10.17516/1997-1370-0140.

Research area: culturology.

\section{Introduction}

The issue of climate change in recent decades has become one of the most controversial issues for the scientific and political communities, and the population as a whole. This is largely due to the scientific research results demonstrating a general increase in global air and ocean temperatures, and also melting glaciers and increased global mean sea level (Kochkin, 2015).
Given this undeniable phenomenon, there is an increasing interest in studying the regional features of climate change, its impact on human activities, and the level of comfortable living in the region as a whole. In this regard the climate of the Krasnoyarsk Territory with its climatic heterogeneity is no exception. This article attempts to systematize the historical stages of studying climate change in the Krasnoyarsk

(c) Siberian Federal University. All rights reserved

* Corresponding author E-mail address: NevolkoN@yandex.ru 
Territory. The article is structured in accordance with this systematization. The authors give a chronological description of the most significant events and research results related to the climate study in the Yeniseysk Governorate (in 1934 it changed its name to the Krasnoyarsk Territory (Krai)).

\section{Research methodology}

To understand and interpret the data on the study of climate change in the Krasnoyarsk Territory the authors used a qualitative method. This method allowed revealing the most important historical events, the conclusions of scientific research that determine the chronology of the study of the regional climatic indicators.

To systematize the available historical information on the study of climate change in the Krasnoyarsk Territory, historical and systemic methods were also applied. The historical method made it possible to analyze the stages of climate studies in the Krasnoyarsk Territory, beginning with the first field expeditions to Siberia in the $18^{\text {th }}$ century. Thanks to the use of the systemic method, it became possible not only to single out certain stages in the history of climate studies in the Krasnoyarsk Territory, but also to detect a trend in the climate studies development in the period from the $18^{\text {th }}$ to the $21^{\text {st }}$ centuries.

\section{Periodization of historical stages of the climate change studies in the Krasnoyarsk Territory}

The history of the climate change studies in the Krasnoyarsk Territory can be roughly divided into four stages: the $18^{\text {th }}$ century - the discovery of the Siberian territory, the first observations of the weather; the $19^{\text {th }}$ century - the beginning of systematic meteorological climate observations, the collection of factual material; the $20^{\text {th }}$ century (until 1991) - expansion of the system of the climate meteorological observations in the Krasnoyarsk Territory, scientific aggregation of the regional climate features, identification of trends in regional climate change; the end of the $20^{\text {th }}$ - the beginning of the $21^{\text {st }}$ centuries carrying out of scientific research concerning dynamics of climate change in the Krasnoyarsk Territory towards global warming, the analysis of interrelation of human agrotechnical activity of and climate. Next, let us consider each of these historical stages in more detail.

\section{$18^{\text {th }}$ century: a period of large-scale field research in Siberia}

The initial stage of studying climate change in the Krasnoyarsk Territory dates back to the $18^{\text {th }}$ and $19^{\text {th }}$ centuries. Under Peter I the issue of geographical study of Russia occupied one of the priority places among scientific research. At the Emperor's direction, the first scientific expedition in Russia was organized to study the Siberian territories. Peter I invited Daniel Gottlieb Messerschmidt (1685-1735) to be the head of the expedition. During seven years (17201727) systematic study of Eastern Siberia was conducted (Anan'eva et al., 2016). As a result of the work, Messerschmidt prepared a 10-volume "Siberian survey", which included materials on the Yeniseysky Krai (Anan'eva et al., 2016: 22-24). Further study of the Yeniseysk climatic features was made by the Siberian Expedition of 1733-1743, carried out by the researchers from the Russian Academy of Sciences. Among the participants of this expedition were Louis de l'Isle de la Croyère, a French scientist who had worked in St. Petersburg since 1726, Johann Georg Gmelin, German scientist, Gerhard Friedrich Müller, a Russian historiographer of German descent. According to the Senate Decree of December 28, 1732, the expedition members were to monitor the weather conditions in the areas of Eastern Siberia, in particular Yeniseysk, and register the data in the log. Great attention 
was paid to the Yenisei hydrological observations: rising and lowering of the water level, freezing and ice breakup of the river.

Thus, the $18^{\text {th }}$ century marked the beginning of the climate studies history in the Krasnoyarsk Territory (historically - the Yeniseysk Governorate). At the initial stage, the study of the regional climate was based on observations and recording of weather conditions: air temperature, precipitation level, wind direction, atmospheric pressure, etc. Such a study was conducted in the framework of large-scale field events, one of which was the ten-year Siberian Expedition. The climate study of the Yeniseysk Governorate was carried out along with the research in other regions of Eastern Siberia.

\section{$19^{\text {th }}$ century: the initial stage of regional studies}

Empowering the Yeniseysk Governorate with the status of an independent Siberian region (1822) facilitated concentration of the researchers on the natural and climatic features of this particular region. One of the first enthusiasts who devoted his efforts to the description of the Yeniseysk Governorate, including climate change studies, was the first governor of the region, Alexander Petrovich Stepanov (1781-1837). In his work "Yeniseysk Governorate" (1835), A.P. Stepanov along with a description of the physical geography, topography and industry of the Yeniseysk Governorate, presented his thermometric observations of the weather conditions of "some well-known places in the area" (Stepanov, 1835: 55). In particular, he gives the average air temperatures of the territory (in the range from 53 to $55{ }^{\circ} \mathrm{C}$ latitude), as follows: "During the months generally accepted as spring ones frosts reach $-27^{\circ} \mathrm{C}$; and it can be as hot as $+11{ }^{\circ} \mathrm{C}$; ... During the months usually taken for summer ones, the heat reaches $+30{ }^{\circ} \mathrm{C}$; And frosts up to $-7{ }^{\circ} \mathrm{C}$. The warm season begins on June 1; $t$ slowly rises to $+9{ }^{\circ} \mathrm{C}$, quickly to $+15{ }^{\circ} \mathrm{C}$. ... The autumn months are the measure of the cold increase as opposed to its decrease in the spring months... The winter months begin with the fact that in December mercury does not leave the ball; in January the cold extends from -25 to -35 ${ }^{\circ} \mathrm{C}$ and occasionally to $-8{ }^{\circ} \mathrm{C}$, and in February from -20 to $-32{ }^{\circ} \mathrm{C}$ and rarely to $-7{ }^{\circ} \mathrm{C}$ ". As can be seen from this quotation, A.P. Stepanov fixes the variability of weather conditions in the Yeniseysk Governorate, depending on the season. In addition, the author notes that located almost at the same latitude Tobolsk and Yeniseysk have different average air temperatures: Tobolsk $0{ }^{\circ} \mathrm{C} 52$, Yeniseysk $-3{ }^{\circ} \mathrm{C} 58$ '. Such a climate change is conditioned by a number of reasons. A.P. Stepanov distinguishes among them the "deliberate" elevation of the ground; remoteness from the equator; the inclination of the entire plane to the North; the chain of high mountains, obscuring the winds from the south; the number of population; the eastern wind (Stepanov, 1835: 55). Since the latter circumstance (the presence of the eastern wind) does not belong, according to the author, to the Yenisei banks, therefore the eastern character of Yeniseysk is more moderate in contrast to other Eastern countries. Thus, according to A.P. Stepanov, "the Eastern character" affects the temperature change and its volatility. In addition, climate change is under the impact of strong fumes in the form of vapors and hoarfrost.

Apart from describing thermometric observations, A.P. Stepanov lists such natural and climatic features of the Governorate as storms, thunderstorms, hails, rains, the appearance of the rainbow only in the summer. He highlights the Northern Lights as "the most outstanding phenomenon" (Stepanov, 1835: 64). In a word, the A.P. Stepanov's work initiated the regional study of climate change in the Krasnoyarsk Territory. 


\section{Meteorological observations}

Actual meteorological observations began in the Krasnoyarsk Territory in 1838. At that time, the first Krasnoyarsk meteorological station opened and later entered the main network of the Main Physical Observatory of Russia. The first weather observer in Krasnoyarsk was the exiled Decembrist, meteorologist Mikhail Fotievich Mitkov (1791-1849). From January 12, 1835 to January 12, 1848 he made meteorological observations of air temperature, precipitation, cloud cover, pressure and wind. In 1841, the founder of the meteorological observations' system and meteorological service in Russia, Academician A.Ia. Kupfer provided M.F. Mitkov with exemplary meteorological instruments, allowing recording the climate change indicators more accurately. Mitkov's observational materials were of great value to researchers. This is confirmed by numerous sources which published the results of M.F. Mitkov's observations. In particular, these were "A summary of observations made in the Main physical and subordinate observatories in 1861", "Climates of the globe and in Russia in particular" by A.I. Voeikov, "On the air temperature in the Russian Empire" by G.I. Wild, "Breakup and Freezing of Waters in the Russian Empire" by M.A. Rykachev, "Climatological Atlas of the Russian Empire" (1899), "Climate of the Union of Soviet Socialist Republics" (Leningrad, 1931). Alexander Petrovich Belyaev continued his work on observations of climatic changes in the Yeniseysk Governorate - in Minusinsk and Krasnoyarsk, whereas Alexander Ivanovich Yakubovich worked in Turukhansk, Mikhail Matveevich Spiridonov - in Yeniseysk.

A major role in the development of both Russian and regional, climatology was played by the opening of the Main Geophysical Observatory in 1849 in St. Petersburg under the Decree of Nicholas I. This observatory served as a state center regulating meteorological observations throughout Russia. This gave impetus to the fact that many regions began the systematic climate observations. Since 1868 under G.I. Wild as its director the observatory developed standards regulating the scheme of weather observations. In particular, it introduced a unified observation period, a metric system of measures, and began to measure the temperature in degrees Celsius. In 1877, after a thirty-year break, meteorological observations resumed in Turukhansk. Observers at the station were in-migrants and teachers of the parochial school. In 1885, visual observations of weather and precipitation began in the village Kezhemskoe. In 1894, instrumental observations started in the village Kazachinskoe. At the end of the $19^{\text {th }}$ century there were already 13 stations on the territory of the Yeniseysk Governorate (Anan'eva et al., 2016).

\section{Expedition research}

Despite the fact that in the $19^{\text {th }}$ century in the Yeniseysk Governorate there was an opportunity to conduct meteorological observations with the help of technical instruments, field research continued. So, in the period from 1842 to 1845 , by the decision of the Imperial Academy of Sciences, a scientific expedition was organized to the North and East of Siberia. The researchers included a Russian scientist, the founder of permafrost studies Alexander Fedorovich Middendorf (1815-1894). His Siberian expedition had to solve two problems: the study of the organic life on the almost unexplored Taimyr and the study of permafrost. The journey covered a vast territory from Krasnoyarsk along the Yenisei to Dudinka, along the North Siberian lowland to the mouth of Khatanga, and further on, the work continued on the Taimyr Peninsula, with routes within its borders (Anan'eva et al., 2016). A.F. Middendorf was one of the first to describe the nature of the North Siberian lowland and the Byrranga Mountains. In his two-volume 
work "Journey to the North and East of Siberia" (I860-1878), A.F. Middendorf, gave not only a description of the main natural components of the North and East of Siberia, features of life of the indigenous inhabitants of the region, in particular the Yenisei Ostyaks, the Dolgans, the Tungus people, the Yakuts, but he also devoted the third section of the first part of his work to the Siberian climate. The peculiarity of the regional climate, according to the scientist, is a rather large range between extreme degrees of heat and cold, typical of each place in Siberia (Middendorf, 1862: 320). Besides the existing air temperature contrast, A.F. Middendorf mentioned the climate dependence on the huge snow ridges of Siberia going in different parallel chains from the west to the east. The temperature contrast and the presence of snow ridges allowed the researcher to characterize the climate of Siberia as excessive (Middendorf, 1862: 320). According to the author, the severe climate of the North of Siberia is explained by the ice in the depth of the soil, as well as numerous, full of icy water marshes, which cut off the surface from an internal source of terrestrial heat. In addition, thick fogs, thickets of coniferous forests, glaciation of water do not permit soil warming up. According to the author, these circumstances cause the coldness of Siberia (Middendorf, 1862: 320).

A crucial part in the further study of the territory of Russia and Siberia in particular was associated with the creation of the Russian Geographical Society in 1845 in St. Petersburg. In 1851, its Siberian (since 1877 - East Siberian) department was founded in Irkutsk. The society's activities covered a great variety of knowledge fields - from meteorological observations to the study of ancient inscriptions on the rocks of the Yenisei. Thanks to the creation of the Siberian department of the Russian Geographical Society, a database on the natural and climatic regional conditions was enriched with reports and travel essays received by the department. The activities of the society members consisted not only in the collection and analysis of field observation materials, but also in the organization of scientific expeditions and participation in them.

In the second half of the $19^{\text {th }}$ century, certain branches of geographic science stood out as independent areas of knowledge. This contributed to the narrower focus of the further expeditions. So, these were expeditions on climatology, hydrology, geomorphology, soil science, etc. The research results were published in the form of atlases, maps, climatologic monographs. In 1859 on the basis of the Governorate maps and surveys of 1853-1854 the "Map of the southern part of the Yeniseysk Governorate" was compiled. In 1871 P.I. Tretyakov published his book "Turukhansk region, its nature and inhabitants", which contained sufficiently detailed information about the regional climate. The author paid attention to the phenomena typical of a specific season of the year, such as bird migration, precipitation, water tide, and the appearance of the Northern Lights. Together with a general description of the natural and climatic features of the region, P.I. Tretyakov delineated the tendency of a sharp change in temperature in the Turukhansk region within ten days. He wrote: "Thus, on May 20, 1860, at $-2{ }^{\circ} \mathrm{C}$, it snowed and nature was still winter in character, and in 4 days in the air, saturated with fumes and full of electricity, lightnings flashed and thunder rumbled. The next day, at $+28^{\circ} \mathrm{C}$, the thunderstorm recurred, and on May 31 , it was already $+30{ }^{\circ} \mathrm{C}$ in the sun" (Tretyakov, 1871: 64). In this paper, for the first time, the issue of crop dependence on weather conditions was discussed. For example, hot summer and late frost, according to P.I. Tretyakov, are the conditions for a successful outcome of the barley, Brassica rapa, radish, rutabaga, cabbage growth (Tretyakov, 1871: 64). In line with this, the author touches upon the issue of perception by "non- 
Russians" (Tretyakov, 1871: 64) of the seasons. So, according to him, for non-Russians a year consists of 13 months, some peoples, such as the Samoyeds and the Tungus people, divide winter and summer into two separate years. The Tungus people, according to P.I. Tretyakov'a observations, do not separate the summer by months. Thus, P.I. Tretyakov referred to quite a wide spectrum of issues related to the climate of the Turukhansk region. Among them, there were a peculiarity of a sharp change in air temperature in the region, the dependence of the harvest on weather conditions, the social perception of the seasons.

Along with the intensive accumulation of factual material, writing monographs (mostly containing the author's personal impressions on observations of the weather conditions' changes), maps and atlases, this was the period of developing theoretical issues of climate studies, such as atmospheric circulation, long-term climate variations, etc. One of the outstanding scientists who made a huge contribution to the theoretical study of climate change, both in Russia and in the Siberian region, was Alexander Ivanovich Voeikov (1842-1916). In his work "The climates of the globe and Russia in particular" (1884), A.I. Voeikov went for the analysis of climatic features of Western and Eastern Siberia. In particular, he showed the dependence of the geographic location of the Siberian regions on climate indicators. Since the beginning of the $20^{\text {th }}$ century, A.I. Voeikov worked as a scientific consultant in the Main Geophysical Observatory in St. Petersburg, thereby giving a rise to a scientific development of climate change issues. Later in 1949, during the celebration of the $100^{\text {th }}$ anniversary of the Main Geophysical Observatory it got the name of this famous Russian climatologist - A.I. Voeikov.

In general, in the history of studying climate change in the Krasnoyarsk Territory, the $19^{\text {th }}$ century was the proof of the fact that, firstly, the role of regional climate studies was growing.
There was an interest not only in the climate of Western and Eastern Siberia as a whole, but also in the systematic observations of the climate in the individual regions of the Yeniseysk Governorate(Turukhansk, Minusinsk, Yeniseysk, Kezhemskoe, Kazachinskoe). Secondly, the emergence of meteorological stations in the Yeniseysk Governorate opened the way to more accurate recording of the observed changes in weather and climate conditions. Beyond that, thanks to the opening of the Main Geophysical Observatory, the Center for Meteorological Observations in Russia, not only a unified scheme for observing the weather was being developed, but also there was formed a basis for scientific research on climate change issues. As well as the great interest of voluntary societies and individuals was shown in conducting meteorological observations of the weather of the Yeniseysk Governorate (the enthusiasts included the governor of the Yeniseysk Governorate A.P. Stepanov, the Decembrists - A.P. Belyaev, A.I. Yakubovich, M.M. Spiridonov, doctors, teachers, immigrants), scientists A.F. Middendorf, A.I. Voeikov and others inspired the research on climate change in Siberia.

\section{The $20^{\text {th }}$ century (until 1991):}

\section{the development of scientific regional studies}

During the $20^{\text {th }}$ century, the study of climate change in the Krasnoyarsk Territory was carried out in several directions.

First, the Academy of Sciences continued to organize the expeditions to Siberia. In particular, in the 1920s, expeditionary research was launched in various parts of the country, including the north of Western Siberia and the mountains of Southern Siberia. In Northeastern Siberia, S.V. Obruchev carried out extensive research, as a result of which the concept of the orography of Kolyma-Indigirsky Krai (province) radically changed (Isachenko, 1971). 
Secondly, the network of meteorological stations within the Krasnoyarsk Territory was expanding. Whileinthe $19^{\text {th }}$ centurymeteorological stations were located only in a few areas of the Krasnoyarsk Territory, in particular in Yeniseysk (observations had been made since 1853), in Krasnoyarsk (observations had been made since 1883), in Boguchansky District (since 1887), and in Kansk (since 1895), since the beginning of the $20^{\text {th }}$ century, the list of administrative regions in which systematic meteorological observations began was growing significantly. The main parameters for conducting meteorological observations were the air temperature regime, the wind direction and speed, and the amount of precipitation. In the $20^{\text {th }}$ century, the spectrum of meteorological observations was expanding. Observations concerned not only temperature and precipitation, but also air humidity, wind, atmospheric phenomena, sunshine, and soil temperature. As a result of such observations, the researchers detected the change in the average annual air temperature in Krasnoyarsk upward by 0.2-0.9 degrees, and in the center of the city - by 1.5-1.7 degrees. Of considerable importance for the development of meteorological observations in the Krasnoyarsk Territory was signed by V.I. Lenin the decree "On the organization of the RSFSR meteorological service" of June 21, 1921. Since that time the Krasnoyarsk Territory has seen centralized, united by a uniform methodology, equipped with the homotypic instruments meteorological observations' service (Shver, Gerasimova, 1982).

Thirdly, the construction of the largest industrial facilities in the region required not only the provision of their employees with hydrometeorological information, but also impact analysis of facilities on the regional climate. In this regard, on October 1, 1939, the Krasnoyarsk Administration of theUnitedHydrometeorological Service began its work. In 1978 it was renamed as the Krasnoyarsk Territorial Administration for Hydrometeorology and Control. From 1975 to 1977 , Krasnoyarsk obtained two stations (one on the Otdykha island, the other - on the Lysaya Mountain) and seven posts in different parts of the city to determine the effect of the reservoir on the city's climate and to study its microclimate.

The Hydrometeorological Service was in charge of an analysis of climate change in the region, the compilation of data and the delivery of information to the public. In this case, it is worth noting the growth in publications containing information on the regional climate. Before 1917, the observation materials were not published in summary, or published only in various special editions, so they were not available and were often bibliographic rarities (Fedorov, 1928), since the 1920s, meteorological observations have begun to be published more widely in the form of climatological data sheets and brochures. In particular, the Main Geophysical Observatory in the 1920s began publishing the series "Climate of the USSR" and selected issues of the USSR Climatological Atlas, which included information on the Krasnoyarsk Territory climate.

The next trend in the study of climate change in the Krasnoyarsk Territory is related to scientific research. Especially large scientific studies of the regional climate change were conducted in the second half of the $20^{\text {th }}$ century the first decades of the $21^{\text {st }}$ century. For instance, N.S. Fedorov conducted a comparative analysis of the data of meteorological stations in the Krasnoyarsk region during 1911-1926, concluding about the inconstancy of climatic factors in the region. The scientist pointed out the tendency of climate change and the influence of climatic conditions on human life and nature as a whole: "Studying the year seasons, distinguished according to local peculiarities, I found that in Krasnoyarsk, Kazachinskoe experimental field and Yeniseysk, i.e. in the agricultural area, there 
are 3 seasons (spring, summer and autumn) with temperature above zero, in Verkhneimbatsky two seasons (summer and autumn), and north - in Monastyrsky and Dudinka - only one summer. All this indicates a great progression of the severity of the climate towards the north and leaves its imprint on the surrounding nature, plant and animal life and on man and his economy" (Fedorov, 1928: 9). Moreover, N.S. Fedorov, analyzing the climatic indicators of the first quarter of the $19^{\text {th }}$ century and the beginning of the $20^{\text {th }}$ century, descried similar trends, namely the alternation of cold and warm air temperature within the allocated time intervals. Admitting the increase in the pace of economic processes in the 1920s, the scientist envisaged a further line of research on climate change related to the need for a more thorough study of the Krasnoyarsk Territory climate in connection with the practical expediency of meteorological observations (Fedorov, 1928: 9). This vector of scientific research was supported in the 1930s due to the realization of the pragmatic importance of climate indicators accumulated during observations for the agricultural development. This led to the development of agricultural climatography in the 1930s. Since that time, a qualitatively new stage has begun in the climate change studies in the Krasnoyarsk Territory, which have been characterized by a rethinking of approaches to the analysis of meteorological observations. The study of climate change for practical purposes, for the needs of society, necessitated a different, specialized weather observation system, other methods of processing materials and a special climate characteristic for agriculture, transport and industrial construction, aviation, etc. (Mirotvortsev, 1934).

In the second half of the $20^{\text {th }}$ century there was a tendency of scientists' interest in the specific climatic conditions of certain regions in the Krasnoyarsk Territory. Take one example,
K.N. Nikolskii devoted his study to the conditions for the formation of secondary cyclones over the areas of the Minusinsk Basin, which were notable for intense precipitation (Nikolskii, 1960). The change in air temperature, namely the contrast of temperature, is discussed in relation to the formation of secondary cyclones. K.N. Nikolskii comes to the conclusion that an in most cases (88 $\%)$ increase in the average temperature contrasts in the frontal zone (the areas south-west of the Minusinsk Hollow) is preceded by the secondary cyclones over the south of the Krasnoyarsk Territory. Likewise, the scientist analyzes climate change from the viewpoint of the evolution of the cloud cover of precipitation, which is connected with the secondary cyclones over the southern regions of the Krasnoyarsk Territory.

The climatic features of the administrative center of the Krasnoyarsk Territory were complied in the work "Climate of Krasnoyarsk" (1982) by Ts.A. Shver and A.S. Gerasimova. The authors characterize the main elements of the city's climate, in particular, the Krasnoyarsk wind conditions, air humidity, atmospheric precipitation, snow cover, cloud cover, mesoand microclimate peculiarities of the city; also they paid attention to the city air pollution in. The authors see a direct dependence of climatic indicators on the city industry. Krasnoyarsk with its infrastructure, according to the scientists' conclusions, affects the climate significantly. Transparency and purity of air decrease, the air temperature in winter is higher than in the suburbs. Therewith the authors noticed a tendency towards some slight increase in the city air temperature and to some increase in precipitation (Shver, Gerasimova, 1982).

Thus, the period from 1900 to 1991 is characterized as a period of noteworthy turns in the study of climate change in the Krasnoyarsk Territory. Expansion of the meteorological stations' network, their technical improvement, 
development of the regional infrastructure led to the need to analyze interference of climate and the life of the population and, vice versa, anthropogenic impact on climate change. The analysis of climatic indicators in the Krasnoyarsk Territory allows scientists to speak about the trend of the regional climate change towards the increase in average air temperature.

The end of the $20^{\text {th }}$ - beginning of the $21^{\text {st }}$ centuries (1991-2000s): an interdisciplinary approach as a basis for scientific regional studies

At this stage, scientists have a fairly large database of climate observations, in particular in the Krasnoyarsk Territory, which allows us to talk about the trend of climate change. The theme of climate change has become, as never before, one of the most controversial issues discussed not only by academic community, but also politicians and the population as a whole. This is due to the fact that climate changes have an increasing influence not only on the natural environment, but also on human life in all over our planet (Oparin et al., 2013). Since the increase in air temperature is observed all over the globe and the climate warming has been admitted to be an undeniable phenomenon in recent decades (Kochkin, 2015), at the present stage the issue of climate change is customarily considered in the context of global warming. Various scientific discussion platforms in different countries are devoted to this topic. For example, in 1992, Rio de Janeiro hosted a conference, also known as the Earth Summit or the United Nations Conference on the Protection of the Environment and Development (UNCED). In 2015, a climate conference was held in Paris. The purpose of the conference was to sign an international agreement to maintain an increase in the average temperature of the planet below 2 ${ }^{\circ} \mathrm{C}$ (for all countries). The scientific and political communities of the Krasnoyarsk Territory also join the global attempts to study the issue of global warming, in particular, to explore regional peculiarities of this phenomenon. So, in April 2017, Siberian Federal University in Krasnoyarsk hosted an international conference on the interdependence of the history of society and climate variability on the example of the Altai mountainous country. This conference was attended by scientists from the world leading scientific centers, which deal with various aspects of the history of climate studies and the society development during the last two millennia. In addition to the organization of discussion platforms, the Krasnoyarsk Territory welcomes scientific research of climate change. There are several aspects which scientific research is concentrated on. These are issues of the regional dynamics of changes in air temperature, the impact of changes in the regional climatological factors on the quality of crops, the reconstruction of the past eras' climate for understanding contemporary climatic trends, and predicting the consequences of global warming for Siberia as a whole.

Thus, having accumulated data of meteorological observations of the climate in the Krasnoyarsk Territory, researchers get the opportunity to reconstruct the regional dynamics of climate change, mainly towards the increasing annual average air temperature and increasing precipitation (Konnikova, 2016; Emel'ianov, 2016). In particular, referring to the climatic indicators of the Krasnoyarsk Territory Stolby Reservation, the systematic collection of which has been conducted since 1927, scientists see an increase in the average annual air temperature. The period of the greatest warming, according to the researchers' findings, is during the decade at the turn of the century (1993-2003) (Ovchinnikova et al., 2011).

Even the scientists of classical Greece drew attention to the dependence of human on the 
natural environment (mainly on the climate). This dependence was associated not only with the crop yield, but also with shaping of the psyche and the character of man (Hippocrates from Kos (460-377 BC)). Aside from that, the ability to govern peoples also depended on the natural conditions and geographical location of their territory (Thucydides (circa 460-400 BC), Xenophon (circa 430-355)) (Isachenko, 1971). At the present stage of the climate change studies in the Krasnoyarsk Territory, the issue of the dependence of the life comfort on climatic indicators becomes topical. One parameter of the life comfort of the population is a high level of agricultural productivity. V.A. Bezrukikh and O.Iu. Elin scrutinize the relationship between climate conditions and agricultural production. The authors came to the conclusion that for agricultural production it is vital not only to estimate climatic resources, butalso to substantiate the ways of their qualitative use, in particular, to maximize the use of atmospheric humidification resources (Bezrukikh, Elin, 2010).

One of the most important sources of studying climate change is historical information, which allows us to comprehend the current situation of climate change (Myglan, 2010). Reconstruction of climatic features in Southern Siberia in the $18^{\text {th }}$ and $19^{\text {th }}$ centuries and their influence on the population economic activity is presented in the works of V.S. Myglan (2010), D.V. Ovchinnikov, E.A. Vaganov, D.F. Zhirnova (2007). There is a direct correlation between the change in the crop yield, the variability of the livestock numbers and the dynamics of climatic characteristics. The authors found confirmation that the climatic factor affect the crop yield on the basis of a comparative analysis of tree-ring chronologies and modern crop yields in the south of the Krasnoyarsk Territory, as well as on the basis of historical material in relation to the amount of crop yield in the $18^{\text {th }}$ and $19^{\text {th }}$ centuries.
Anotherdirection forstudying climate change in the Krasnoyarsk Territory is connected with the flora analysis; on the one hand, it is a sphere affected by environmental change (Kuznetsova, 2007), on the other hand, it is a bioindicator of climate change (Ovchinnikova et al., 2011). Analyzing the vegetation process of the tree species in the Krasnoyarsk Stolby Reservation, a number of scientists (T.M. Ovchinnikova, V.A. Fomina, E.B. Andreeva, N.P. Dolzhkovaia, V.G. Sukhovolskii) discovered the vegetative stage dynamics between 1952 and 2008. Researchers observe an earlier (for two weeks) vegetation of tree species, especially in the last two decades. However, according to the authors' observation, from 1984 to 2002 there had been a linear tendency towards early frondescence, then since 2003 there was no such tendency.

The next important aspect of studying climate change at the present stage is the issue of forecasting the consequences of climate change in Siberia. Among such consequences are the increase in surface temperature, precipitation and the depth of permafrost thawing; the flooding of the North of Western Siberia due to the sea level rise. According to climatic forecasting, B.T. Kochkin states the appearance of broad-leaved species in the Krasnoyarsk regional taiga forests. Significant climate change in Siberia with an increase in average annual temperatures by $10^{\circ} \mathrm{C}$ is not expected (Kochkin, 2015).

The climate change in the Krasnoyarsk Territory is studied not only from the point of view of natural science, but also in the context of socioanthropological and cultural studies of territories where the indigenous small-numbered peoples of the North and Siberia live compactly. Beginning in 2010, the scientists have been carrying out regular research of the indigenous peoples living in extreme climate and landscape conditions in the territories of the Siberian Arctic. These researchers are A.E. Amosov (Amosov et al., 
2012), N.P. Koptseva (Koptseva, 2015; Koptseva et al., 2016a, Koptseva et al., 2016b; Koptseva, Kolesnik, 2016); V.I. Kirko (Kirko et al., 2010; Kirko et al., 2013; Kirko, 2015); Iu.S. Zamaraeva, M.I. Bukova (2016), K.V. Reznikova (Reznikova et al., 2016), N.N. Pimenova (Pimenova, 2012; Pimenova, 2016), M.A. Kolesnik, V.S. Luzan (Luzan, 2016), A.A. Sitnikova (Sitnikova, 2015), E.A. Sertakova (Sertakova, Avdonina, 2016), N.M. Libakova (Libakova, 2015, Libakova et al., 2016), N.G. Shishatskii (Shishatskii et al., 2012), A.V. Kistova (Kistova and Sevruzhenko, 2016), Iu.N. Avdeeva (Avdeeva and Libakova, 2015) and some other scientists.

Thus, the peculiarity of the modern climate change studies of in the Krasnoyarsk Territory is, first of all, the relevance of the interdisciplinary approach. The study of the regional climate, mainly the change in climatic indicators, occurs at the intersection of climatology, history, biology and chemistry. Such an approach allows scientists not only to verify the exact indicators of the regional climate change, but also to forecast the weather in the future, as well as the expected consequences of the global warming process.

\section{Conclusion}

An analysis of the history of the climate change studies in the Krasnoyarsk Territory allows us to draw the following conclusions:

1. The history of the climate change studies in the Krasnoyarsk Territory can be conventionally divided into four stages according to the most significant events related to the study of natural and climatic features of the territory.

2. The initial period of climate research in the Krasnoyarsk Territory is the $18^{\text {th }}$ century. This time first saw large-scale field studies of the Siberian territory, including the study of the geographic location of the region, its orographic structure, flora, fauna, and climate observations. The first information of climate observations was recorded in travel notes of pioneers-naturalists.

3. The second stage is the $19^{\text {th }}$ century, during which the role of regional climate studies increases meaning that researchers focus not on the Siberian weather in general, but on certain territories of the Yeniseysk Governorate. In addition, during this period, the first meteorological stations appeared in Krasnoyarsk, Yeniseysk and enabled more accurate recording the observed climate changes in some areas of the region.

4. The period from 1900 to 1991 in the history of studying climate change in the Krasnoyarsk Territory is characterized by expanding the network of meteorological stations and their technical improvement. The researchers start to study a new aspect of climate, related to the development of the regional infrastructure, the need to develop the country's economy, and accordingly, necessitating an analysis of the climate's influence on the life of the population and, vice versa, anthropogenic impact on the climate change. For the first time, scientists raise the issue of the climate change trend in the region as regards an increase in the average air temperature.

5. At the end of the $20^{\text {th }}$ and beginning of the $21^{\text {st }}$ centuries, the study of climate change in the Krasnoyarsk Territory is carried out within the framework of an interdisciplinary approach that allows scientists not only to verify the exact indicators of the regional climate change, but also to forecast the weather in the future, as well as to foresee the consequences of global warming.

\section{References}

Amosov, A.E., Bokova, V.I., Bakhova, N.A. (2012). Indigenous and Small in Number Peoples of the North Siberia under the Global Transformations (on the Material of the Krasnoyarsk Territory). 
Conceptual and Methodological Basis of the Research. Ethno-cultural Dynamics of Indigenous Peoples of the Krasnoyarsk Territory (Part 1). Russia, Krasnoyarsk, 2012.

Anan'eva, T.A., Chekha, V.P., Elin, V.A. et al. (2016). Fizicheskaia geografiia Krasnoiarskogo kraia: uchebnoe posobie [Physical geography of the Krasnoyarsk Territory: a textbook]. Krasnoyarsk, KSPU named after V.P. Astafyev, 294 p.

Anokhina, R., Balukova, N. (1961). Pogoda i urozhai (po materialam Krasnoiarskogo kraia [Weather and harvest (based on the Krasnoyarsk Territory materials)]. Krasnoyarsk, Krasnoyarsk book publishing house, $71 \mathrm{p}$.

Avdeeva, Iu.N., Libakova, N.M. (2015). Mezhdunarodnye praktiki sotsiokul'turnogo proektirovaniia po otnosheniiu k korennym malochislennym narodam Severa, Sibiri i Dal'nego Vostoka [International practices of socio-cultural design in relation to the indigenous small-numbered peoples of the North, Siberia and the Far East], In Sotsiodinamika [Socio-dynamics], 10, 10-38. DOI: 10.7256/2409-7144.2015.10.1643, available at: http://e-notabene.ru/pr/article_16430.html

Bezrukikh, V.A., Elin, O.Iu. (2010). Agroklimaticheskie resursy kak factor sel'skokhoziaistvennogo osvoeniia Prieniseiskoi Sibiri [Agroclimatic resources as a factor in the agricultural development of the Yenisei Siberia], In Vestnik KGPU im. V.P. Astaf'eva [Bulletin of KSPU named after V.P. Astafyev], 3, 281-287.

Bukova, M.I. (2016). Osobennosti etnokul'turnogo samosoznaniia etnicheskoi gruppy chulymtsev, kompaktno prozhivaiushchikh na territorii derevni Pasechnoe Tiukhtetskogo raiona Krasnoiarskogo kraia (Tsentral'naia Sibir') [Features of ethnocultural self-identity of the ethnic group of Chulyms, living compactly in Pasechnoye village in the Tyukhtetsky District of the Krasnoyarsk Territory (Central Siberia)], In Sotsiodinamika [Socio-dynamics], 4, 41-51. DOI: 10.7256/2409-7144.2016.4.18414, available at: http://e-notabene.ru/pr/article_18414.html

Emel'ianov, D.V. (2016). Zonal'nye osobennosti izmeneniia klimata lesotundrovoi i taezhnoi zon Krasnoiarskogo kraia [Zonal features of climate change in the forest-tundra and taiga zones of the Krasnoyarsk Territory], In Ekologiia iuzhnoi Sibiri i sopredel'nykh territorii [Ecology of Southern Siberia and adjacent territories], 16-17.

Fedorov, N.S. (1928). K kharakteristike klimata Krasnoiarskogo okruga Sibkraia [On the characteristics of the climate in the Krasnoyarsk region of Sib. Krai]. Krasnoyarsk, 36 p.

Isachenko, A.G. (1971). Razvitie geograficheskikh idei [Development of geographical ideas]. Moscow, Mysl', 416 p.

Istoriia otdela klimata FGBU "Srednesibirskoe upravlenie po gigrometeorologii i monitoring okruzhiushchei sredy". Stanovlenie i razvitie [The history of the climate department of the Federal State Budget Institution "Central Siberian Department for Hydrometeorology and Environmental Monitoring”. Foundation and development], available at: http://meteo.krasnoyarsk.ru

Kabanov, A.A. (1968). Prirodnye usloviia Emel'ianovskogo raiona Krasnoiarskogo kraia kak factor razvitiia ego sel'skokhoziaistvennogo proizvodstva: avtoreferat dis. ... kand. geogr. nauk [Natural conditions of the Emelyanovsk region of the Krasnoyarsk Territory as a development factor for its agricultural production: Abstract for Thesis for Candidate of Geographical Sciences]. Krasnoyarsk, 32 p.

Kirko, V.I. (2015). Postsovetskie praktiki sokhraneniia etnokul'turnoi identichnosti korennykh narodov Severa i Sibiri v Krasnoiarskom krae Rossiiskoi Federatsii [Post-Soviet practices of 
preserving the ethno-cultural identity of the indigenous peoples of the North and Siberia in the Krasnoyarsk Territory of the Russian Federation], In Sotsiodinamika [Socio-dynamics], 6, 113-133. DOI: 10.7256/2409-7144.2015.6.15607, available at: http://e-notabene.ru/pr/article_15607.html

Kirko, V.I., Bukharov, A.V., Keush, A.V. (2010). Otsenka innovatsionnogo potentsiala tipovykh territorial'no-administrativnykh obrazovanii Krasnoiarskogo kraia [Assessment of the Innovation Potential of the Model Territorial and Administrative Entities of the Krasnoyarsk Territory], In Innovatsii [Innovations], 12, 78-83.

Kirko, V.I., Koptseva, N.P., Nevzorov, V.N., Nozdrenko, E.A., Slabukha, A.V. (2013). Mezhdistsiplinarnye ekspeditsii - effektivnyi sposob formirovaniia komand dlia realizatsii kompleksnykh innovatsionnykh i investitsionnykh proektov [Interdisciplinary Expeditions as an Effective Method for Forming Teams for the Implementation of Integrated Innovative and Investment Projects], In Arktika i Sever [Arctic and the North], 13, 4-13.

Kistova, A.V., Sevruzhenko, N.S. (2016). Koreitsy v sovremennoi Rossii: rol' etnicheskikh men'shinstv [Koreans in modern Russia: the role of ethnic minorities], In Sotsiodinamika [Sociodynamics], 3, 62-72. DOI: 10.7256/2409-7144.2016.3.18204, available at: http://e-notabene.ru/pr/ article_18204.html

Kochkin, B.T. (2015). Dolgosrochnyi prognoz klimaticheskikh izmenenii v raione razmeshcheniia khranilishcha vysokoradioaktivnykh otkhodov (uchastok Eniseiskii, Krasnoiarskii krai [Long-term forecast of climate change in the area of of highly radioactive waste storage (the Yeniseysky area, Krasnoyarsk Territory)]. In Geoekologiia. Inzhenernaia geologiia. Gidrogeologiia. Geokriologiia [Geoecology. Engineering geology. Hydrogeology. Geocryology], 2, 119-132.

Konnikova, A.E. (2016). Osobennosti izmeneniia klimata lesostepnoi i stepnoi zon Krasnoiarskogo kraia [Features of climate change in the forest-steppe and steppe zones of the Krasnoyarsk Territory], In Ekologiia Iuzhnoi Sibiri i sopredel'nykh territorii [Ecology of Southern Siberia and adjacent territories], 120-121.

Koptseva, N. (2015). The current economic situation in Taymyr (the Siberian Arctic) and the prospects of indigenous peoples' traditional economy, In Economic Annals-XXI, Ukraine, 9-10, 95-97.

Koptseva, N.P., Kolesnik, M.A. (2016). Formirovanie pozitivnoi kul'turnoi identichnosti kak factor natsional'noi bezopasnosti sovremennoi Rossii. Rezul'taty assotsiativnogo eksperimenta s assotsiatom "russkoe" (na material issledovaniia studencheskokh grupp Sibirskogo federal'nogo universiteta [Formation of Positive Cultural Identity As a Factor of Modern Russia National Security. Results of the Associative Experiment with the "Russian" Association (on Material of the Student Groups' Study in the Siberian Federal University)], In Natsional'naia bezopasnost'/nota bene [National security/nota bene], 1, 129-148.

Koptseva, N.P., Zamaraeva, Yu.S., Kistova, A.V., Pimenova, N.N., Seredkina, N.N., Reznikova, K.V., Fil'ko, A. (2016a). Place Management: Decoding the Visual Image of a Siberian City, In Journal of Applied Economic Sciences, 11 (6), 1144-1156.

Koptseva, N.P., Zamaraeva, Yu.S., Pimenova, N.N., Kistova, A.V., Seredkina, N.N., Reznikova, K.V. (2016b). Regional Peculiarities in Modernization Processes within the Territories of Central Siberia, In International Review of Management and Marketing, 6 (4), 857-865.

Kosovanov, V.P., Krasnozhenova, M.V., Smirnov, B.P. (eds.) (1928). Izvestiia Sredne-Sibirskogo otdela gosudarstvennogo Russkogo geograficheskogo obshchestva [Proceedings of the Central 
Siberian Department of the State Russian Geographical Society], 3, 3, VI. Krasnoyarsk, State Printing House, $81 \mathrm{p}$.

Kuznetsova, G.V. (2007). Izuchenie izmenchivosti u klimatipov kedra sibirskogo pine (pinus sibirica du tour) na iuge Krasnoiarskogo kraia [The study of variability in different climatic types of Siberian pine (pinus sibirica du tour) in the south of the Krasnoyarsk Territory], In Khvoinye boreal'noi zony [Coniferous in the boreal zone], XXIV, 4-5, 423-426.

Libakova, N.M. (2015). Upravlenie zdravookhraneniem dlia korennykh narodov tsentral'noi Sibiri [Health Sphere Management for the Indigenous Peoples of Central Siberia (on the Material of the Krasnoyarsk Territory Analysis)], In Trendy i upravlenie [Trends and Management], 4, 380-394.

Libakova, N.M., Sertakova, E.A., Kolesnik, M.A., Sitnikova, A.A., Il’beikina, M.I. (2016). Sovremennye strategii sotsial'nogo pozitsionirovaniia sibirskikh regionov [Modern strategies for social positioning of Siberian regions], In Sotsiodinamika [Socio-dynamics], 1, 162-189. DOI: 10.7256/24097144.2016.1.17420, available at: http://e-notabene.ru/pr/article_17420.html

Luzan, V.S. (2016). K voprosu o vlianii kul'turnoi politiki na sovremennye lokal'nye identichnosti [On the impact of cultural policy on contemporary local identities], In Sotsiodinamika [Socio-dynamics], 2, 47-66. DOI: 10.7256/2409-7144.2016.2.17733, available at: http://e-notabene.ru/pr/article_17733. html

Middendorf, A.F. (1862). Puteshestvie na sever $i$ vostok Sibiri. Ch. 1: Sever i vostok Sibiri v estestvenno-istoricheskom otnoshenii. Vyp. 3. Otd. 3.: Klimat Sibiri [Journey to the North and East of Siberia. Part 1: North and East of Siberia in natural and historical sense. Issue 3. Section 3: The climate of Siberia]. St. Petersburg, Publishing house of the Imperial Acad. of Sciences, 315-490, I-XXV.

Mirotvortsev, K.N. (1934). Klimat Vostochnosibirskogo kraia [Climate of the East Siberian Krai]. Moscow, Irkutsk, 206 p.

Myglan, V.S. (2010). Klimat i sotsium Sibiri v malyi lednikovyi period [The climate and society of Siberia in the Little Ice Age]. Krasnoyarsk, Siberian Federal University, 230 p.

Myglan, V.S., Ovchinnikov, D.V., Vaganov, E.A., Zhirnova, D.F. (2007). Vlianie klimaticheskikh izmeneii na khoziaistvennuiu deiatel'nost' naseleniia Iuzhnoi Sibiri v "Malyi lednikovyi period" [The influence of climate changes on the economic activities of the Southern Siberia population in the "Little Ice Age". In Geografiia i prirodnye resursy [Geography and natural resources], 1, 90-96.

Nikolskii, K.N. (1960). Obrazovanie chastnykh tsiklonov nad iuzhnymi raionami Krasnoiarskogo kraia [The formation of secondary cyclones over the southern regions of the Krasnoyarsk Territory], In Trudy glavnoi geofizicheskoi observatorii imeni A.I. Voeikova. [Proceedings of the main geophysical observatory named after A.I. Voeikov], ed. by O.A. Drozdov, 88, 125-132.

Oparin, R.V., Bukhtueva, T.N., Mandych, A.F. et al. (2013). Izmenenie klimata i ego posledstviia $v$ Altae-Saianskom ekoregione [Climate change and its consequences in the Altai-Sayan ecoregion]. Krasnoyarsk, $126 \mathrm{p}$.

Ovchinnikova, T.M., Fomina, V.A., Andreeva, E.B., Dolzhkovaia, N.P., Sukhovolskii, V.G. (2011). Analiz izmenenii srokov sezonnykh iavlenii u drevesnykh rastenii zapovednika Stolby v sviazi $\mathrm{s}$ klimaticheskimi faktorami [Analysis of changes in the timeline of seasonal events in woody plants of the Stolby Reservation in connection with climatic factors], In Khvoinye boreal'noi zony [Coniferous in the boreal zone], XXVIII, 1-2, 54-59. 
Pimenova, N.N. (2016). Mechanisms of Socio-Cultural Changes in the Indigenous Peoples of Siberia and the North: the Concept of Cultural Injury of P. Shtompka, In Sotsiodinamika [Sociodynamics], 3, 37-45.

Pimenova, N.N. (2012). Problems of Education of Children of Indigenous Numbers of Siberia and the North in the Krasnoyarsk Territory, In Innovations in Continuing Education, Russia, 5, 12-18.

Reznikova, K.V. (2015). Jetnichnost' kak kategorija social'nogo poznanija [Ethnicity as a category of social cognition], In Sotsiodinamika [Socio-dynamics], 1, 101-111. DOI: 10.7256/24097144.2015.1.14228, available at: http://e-notabene.ru/pr/article_14228.html

Reznikova, K.V., Pimenova, N.N., Kistova, A.V., Seredkina, N.N., Zamaraeva, Iu.S. (2016). Upravlenie brendingom sibirskoi territorii v svete "novogo regionalizma" [Management of the Siberian territory branding in the light of the "new regionalism"], In Sotsiodinamika [Socio-dynamics], 1, 137161. DOI: 10.7256/2409-7144.2016.1.17395, available at: http://e-notabene.ru/pr/article_17395.html

Sertakova, E.A., Avdonina, E.Iu. (2016). Vynuzhdennaia migratsiia i ee otrazhenie v kinematograficheskom iskusstve [Forced migration and its reflection in cinematographic art], In Sotsiodinamika [Socio-dynamics], 2, 106-116. DOI: 10.7256/2409-7144.2016.2.17747, available at: http://e-notabene.ru/pr/article_17747.html

Shishatskii, N.G., Kirko, V.I., Keush, A.V. (2012). Sotsial-no-ekonomicheskie problem sozdaniia territorii traditsionnogo prirodopol'zovaniia [Socio-economic Problems of Creating Territories of Traditional Land Management], In Arktika i Sever [Arctic and the North], 7, 178-184.

Shuranov, V.V. (2014). Monitoring izmenenii prirodno-klimaticheskogo fona na territoriiakh Krasnoiarskogo kraia [Monitoring of changes in the natural and climatic background in the areas of the Krasnoyarsk Territory], In Nauka i obrazovanie: opyt, problemy, perspektivy razvitiia: materialy XIII mezhdunarodnoi nauchno-prakticheskoi konferentsii [Science and education: experience, problems, development prospects: materials of the $13^{\text {th }}$ International Scientific and Practical Conference]. Ed. by: V.V. Matiushev, E.I. Sorokataia, G.I. Tsuglenok. Krasnoyarsk, Krasnoyarsk State Agrarian University, Part 2, 460-465.

Shver, Ts.A., Gerasimova, A.S. (eds.) (1982). Klimat Krasnoiarska [Climate of Krasnoyarsk]. Leningrad, Gidrometeoizdat, 229 p.

Sitnikova, A.A. (2015). Indigenous Education: Actual Status and Problems. Pedagogy and Education, issue 3, 300-311.

Stepanov, A.P. (1835). Eniseiskaia guberniia [The Yeniseysk Governorate]. St. Petersburg, Konrad Vingber's Printing House, 603 p.

Taseiko, O.V., Belskaia, E.N., Sugak, E.V. (2015). Prognoz smertnosti naseleniia g. Krasnoiarska $\mathrm{v}$ usloviiakh povyshennykh temperatur s uchetom kachestva atmosfernogo vozdukha [The forecast of death rate of the Krasnoyarsk population in conditions of the increasing temperatures taking into account the quality of atmosphere air], In Reshetnevskie chteniia: materialy XIX mezhdunarodnoi nauchnoi konferentsii [Reshetnev's readings: materials of the $19^{\text {th }}$ International Scientific Conference]. Krasnoyarsk, SibSAU named after M.F. Reshetnev, Part 2, 317-319

Tretyakov, P.I. (1871). Turukhanskii krai, ego priroda i zhiteli [Turukhansk region, its nature and inhabitants]. St. Petersburg, Printing House of V. Bezobrazov \& Co., 316 p.

Voeikov, A.I. (1884). Klimaty zemnogo shara, vosobennosti Rossii [The climates of the globe and Russia in particular]. St. Petersburg, Publishing House of A. Ilyin's Cartographic Institution, 672 p. 
Zhirnova, D.F. (2012). Ob izmenenii klimata zemledel'cheskoi chasti Krasnoiarskogo kraia na rubezhe XXI veka [On climate change in the agricultural part of the Krasnoyarsk Territory at the turn of the $21^{\text {st }}$ century], In Nauka i obrazovanie: opyt, problemy, perspektivy razvitiia: materialy mezhdunarodnoi nauchno-prakticheskoi konferentsii [Science and education: experience, problems, development prospects: materials of the international scientific and practical conference], 2, 237-241. Krasnoyarsk, KSAU.

\title{
История изучения изменения климата в Красноярском крае
}

\author{
Н.П. Копцева, Н.Н. Середкина \\ Сибирский федеральный университет \\ Россия, 660041, Красноярск, пр. Свободный, 79
}

\begin{abstract}
Статья посвящена анализу истории изучения изменения климата в Красноярском крае. Выделены четыре этапа, на каждом из которых приводится описание основных исторических событий, результатов научных исследований, повлиявших на развитие региональной климатологии, расширения знаний о климате Красноярского края. Динамику развития научных знаний о климате стало возможным проследить на основе анализа содержания как трудов первых исследователей климата Сибири - А.И. Воейкова, А.Ф. Миддендорфа, А.П. Степанова и др., так и современных научных исследований, в частности Д.Ф. Жирновой, В.С. Мыглан, Б.Т. Кочкина и др. Результатом исследования стала упорядоченная система знаний об истории изучения изменения климата в Красноярском крае. Обнаружена тенденция изучения регионального климата не только с позици его изменения в сторону повыщения средней температуры воздуха, но и во взаимовлиянии как антропогенных факторов на повышение климатических показателей, так и изменение климата на качество жизни населения Красноярского края.
\end{abstract}

Ключевые слова: глобальное потепление, изменение климата, история, Красноярский край, метеорологические наблюдения.

Исследование выполнено при финансовой поддержке Российского фонда фундаментальных исследований, Правительства Красноярского края, Красноярского краевого фонда поддержки научной и научно-технической деятельности в рамках научного проекта № 17-16-24601.

Научная специальность: 24.00.00 - культурология. 